medRxiv preprint doi: https://doi.org/10.1101/2021.05.19.21257217; this version posted May 21, 2021. The copyright holder for this preprint (which was not certified by peer review) is the author/funder, who has granted medRxiv a license to display the preprint in perpetuity.

All rights reserved. No reuse allowed without permission.

\title{
Detection of SARS-CoV-2 in saliva using tailed amplicon sequencing
}

\author{
Aaron Garoutte ${ }^{1}$, Tasha M. Santiago-Rodriguez ${ }^{1}$, Heather L. Fehling ${ }^{2}$, Rafal Iwasiow ${ }^{3, *}$ \\ ${ }^{1}$ Diversigen, Inc., Houston, TX, USA, 77046; ${ }^{2}$ Clinical Reference Laboratory, Inc. Lenexa, KS \\ $66215 ;{ }^{3}$ DNA Genotek, Inc., Ottawa, Ontario, CA, K2V 1C2
}

\section{ABSTRACT}

The most recent virus from the Coronaviridae family infecting humans, SARS-CoV-2, has

resulted in a global pandemic. As part of the surveillance efforts, SARS-CoV-2 genomes are

increasingly being made publicly available. Methods that include both short- and long-read sequencing have been used to elucidate SARS-CoV-2 genomes; however, many of these untargeted approaches may require deeper sequencing for greater genome coverage. For this reason, sequence capture or amplicon-based approaches for SARS-CoV-2 genome sequencing have been developed. The present study evaluated a modified sequence capture approach, namely, tailed amplicon sequencing, to determine SARS-CoV-2 near complete genome sequences from the saliva of infected individuals. Particularly, the suitability of saliva samples stored at room temperature using OMNIgene ${ }^{\circledR} \bullet \mathrm{ORAL}$ OME-505 was evaluated. The tailed amplicon sequencing approach poses the additional advantage of being a cost-effective method for library preparation. Different known SARS-CoV-2 variants were identified across the infected subjects, with an average of $>99.4 \%$ genome coverage. This methodology also enabled robust genomic surveillance using phylogenetic analyses. The present study supports the

21 suitability of saliva stored at room temperature using collection devices for SARS-CoV-2 variant 2 detection. Importantly, the present study supports the use of tailed amplicon sequencing 
medRxiv preprint doi: https://doi.org/10.1101/2021.05.19.21257217; this version posted May 21, 2021. The copyright holder for this preprint (which was not certified by peer review) is the author/funder, who has granted medRxiv a license to display the preprint in perpetuity.

All rights reserved. No reuse allowed without permission.

23 approaches as an alternative, cost-effective method for SARS-CoV-2 detection in saliva for

24 genomic surveillance.

Keywords: genomic surveillance; SARS-CoV-2; sequence capture; tailed amplicon sequencing

*Corresponding author email: rafal.iwasiow@dnagenotek.com

INTRODUCTION

Human saliva is home to over 700 microbial species, and serves as protection against

32 bacterial, fungal and viral infections that could potentially reach the respiratory tract (Kilian et

33 al., 2016). It is composed of water and the secretion of salivary glands, dental plaque, as well as

34 nasal and bronchial secretions; thus, several different viruses in human saliva can be identified,

35 some of which may cause disease. The interactions with viruses and specific saliva components

36 can be virus-specific, complex and can potentially influence their detection as a result of the

37 biological functions of saliva (Y. Li et al., 2020). Viruses including, but not limited to hepatitis A

38 (Leon et al., 2015), hepatitis B (Khadse et al., 2016; Parizad et al., 2016), cytomegalovirus (De

39 Carvalho Cardoso et al., 2015), Epstein Barr virus (Kwok et al., 2015), Zika virus (Bonaldo et

40 al., 2016), and Severe Acute Respiratory Syndrome-Associated coronavirus (SARS-CoV) (Wang

41 et al., 2004), have all been detected in the saliva of infected individuals. This has prompted the

42 investigation of saliva as a potential sample type for the diagnosis of several of the mentioned

43 viruses, and of potential emerging and re-emerging viral pathogens.

44 The most recent virus from the Coronaviridae family known to infect humans, SARS-

45 CoV-2 has also been identified in the saliva of infected individuals (Y. Li et al., 2020). While the 
medRxiv preprint doi: https://doi.org/10.1101/2021.05.19.21257217; this version posted May 21, 2021. The copyright holder for this preprint (which was not certified by peer review) is the author/funder, who has granted medRxiv a license to display the preprint in perpetuity.

All rights reserved. No reuse allowed without permission.

origin of SARS-CoV-2 is a subject of ongoing research and speculation, it shares $96 \%$ identity

47 with a bat coronavirus (Zhou et al., 2020), 90\% with coronaviruses present in pangolins (Zhang et al., 2020), and 80\% with SARS-CoV (Zhou et al., 2020). SARS-CoV-2 is known to also be transmitted through aerosol droplets, which may also include salivary droplets. Several studies have identified SARS-CoV-2 in saliva (Han and Ivanovski, 2020; Y. Li et al., 2020), and have

51 proposed its use as an alternative to nasopharyngeal (NP) and oropharyngeal (OP) sample

52 collection, which pose additional discomfort and the need for trained personnel (Yoon et al.,

53 2020). In addition, with the availability of at-home collection kits, subjects are more willing to

54 self-collect saliva(Valentine-Graves et al., 2020). Supervised, self-collected saliva has shown to

55 perform similarly to clinician-collected NP swabs for the detection of SARS-CoV-2 in terms of

56 virus detection and quantification (Noah et al., 2020). Success of detection methods for SARS-

57 CoV-2 depends, among many things, on the persistence and inactivation of the virus and nucleic

58 acids. For example, SARS-CoV-2 is detectable using reverse transcription PCR (RT-PCR) for an

59 average of 18 to 20 days, and up 21 to 26 days in some instances (To et al., 2020; Yoon et al.,

60 2020). Saliva has also been suitable for antibody testing, showing that SARS-CoV-2 antibodies

61 can be detected as early as 10 days (To et al., 2020). This further supports the use of saliva for

62 the detection of SARS-CoV-2 nucleic acids and antibodies. Other factors affecting SARS-CoV-2

63 detection include efficient viral lysis, with various commercially available kits and methods

64 showing varying levels of efficiency (Chu et al., 2020).

The gold standard for the detection of SARS-CoV-2 in any sample type is RT-PCR or

66 quantitative RT-PCR (RT-qPCR) (Takeuchi et al., 2020). As with any PCR-based method,

67 success will depend on primer specificity; thus, the RNA target genome(s) sequence(s) should be

68 known in order to increase sensitivity (D. Li et al., 2020). Other, less evaluated methods for the 
medRxiv preprint doi: https://doi.org/10.1101/2021.05.19.21257217; this version posted May 21, 2021. The copyright holder for this preprint (which was not certified by peer review) is the author/funder, who has granted medRxiv a license to display the preprint in perpetuity.

All rights reserved. No reuse allowed without permission.

69 detection and surveillance of SARS-CoV-2 in various sample types include high-throughput

70 sequencing. RNA high-throughput sequencing was originally used in combination with other

71 methods to identify the novel coronavirus in subjects suffering from pneumonia of unknown

72 origin, showing a similarity close to $90 \%$ to coronaviruses present in bats(Wu et al., 2020). High-

73 throughput sequencing can continue to be used for the surveillance of known and novel SARS-

74 CoV-2 variants, and also to determine genetic diversity, which is usually not provided by RT-

75 PCR or RT-qPCR (Pérez Cataluña et al., 2021). Two approaches have been developed for the

76 detection of SARS-CoV-2 in various sample types using high-throughput sequencing, namely,

77 untargeted and amplicon-based. Untargeted high-throughput sequencing provides the advantage

78 of detecting and monitoring both known and emerging SARS-CoV-2 variants, with the caveat of

79 requiring deeper sequencing to obtain the needed genome coverage for identification, making

80 this approach relatively more cost-prohibiting. Amplicon high-throughput sequencing, or

81 sequence capture methods, have been more widely applied for the detection of SARS-CoV-2 as

82 it represents a more cost-effective approach. One caveat of sequence capture approaches is the

83 failure to cover the entire viral genome as the primers usually cannot cover the genomic ends

84 (Gohl et al., 2020).

85 Approaches, such as the ARTIC network, have developed methods for amplicon pool

86 preparation for the sequencing of SARS-CoV-2 which involve a 'lab-in-a-suitcase' that can be

87 used in remote and resource-limited areas (https://artic.network/1-about.html). In the ARTIC

88 network protocol, the first cDNA strand is enriched by amplifying with two different pools of

89 primers. This generates amplicons tiling the virus genome, which are then subjected to either

90 Illumina or Oxford Nanopore library preparation and sequencing. More recently, a modification

91 to the ARTIC network protocol, known as tailed amplicon sequencing, has been developed to 
medRxiv preprint doi: https://doi.org/10.1101/2021.05.19.21257217; this version posted May 21, 2021. The copyright holder for this preprint (which was not certified by peer review) is the author/funder, who has granted medRxiv a license to display the preprint in perpetuity.

All rights reserved. No reuse allowed without permission.

92 reduce library preparation cost and time (Gohl et al., 2020). The method has been shown to

93 achieve results comparable to the ARTIC network protocol (Gohl et al., 2020). Briefly, in the

94 tailed amplicon approach, the first cDNA strand is enriched using the ARTIC v3 primers. In this

95 case, the primers also contain adapter tails that allow sequencing libraries to be created through a

96 second indexing PCR. This, in turn, adds sample-specific barcodes and flow cell adapters.

97 Notably, this modification to the ARTIC protocol has not been extensively tested in saliva

98 samples. Therefore, the main aim of the present study was to evaluate the suitability of the

99 modified tailed amplicon sequencing protocol for the detection of SARS-CoV-2 and its ability to

100 discern potential variants in human saliva.

102 MATERIALS AND METHODS

103 Sample collection and RNA extraction

104 Saliva samples were collected from various geographical locations in United States using

105 the OMNIgene ${ }^{\circledR} \cdot$ ORAL OME-505 device (DNA Genotek, Inc) and shipped to Clinical

106 Reference Laboratory, Inc. for testing using the CRL Rapid Response ${ }^{\mathrm{TM}}$ COVID-19 Test. After

107 testing, the remaining saliva samples collected and stabilized in the OMNIgene $₫ \bullet O R A L ~ O M E-$

108505 devices, were stored at room temperature for up to 15 days prior to RNA extraction (Table

109 1). At a later point, one to fifteen days post diagnosis, eight randomly selected samples from a

110 pool of samples which had previously tested positive for SARS-CoV-2 by the CRL Rapid

111 Response ${ }^{\mathrm{TM}}$ COVID-19 Test were selected to be sequenced. The only criteria used for sample

112 selection was an initial $\mathrm{Ct}$ value <30 (Table 1). The randomly selected samples were extracted

113 using the Zymo Quick RNA/DNA Viral MagBead kit (Cat. No. R2141) following

114 manufacturer's instructions. 
medRxiv preprint doi: https://doi.org/10.1101/2021.05.19.21257217; this version posted May 21, 2021. The copyright holder for this preprint (which was not certified by peer review) is the author/funder, who has granted medRxiv a license to display the preprint in perpetuity.

All rights reserved. No reuse allowed without permission.

\section{Sample processing, sequencing and bioinformatic analyses}

The extracted RNA was then prepared and sequenced using previously described

118 methods in Gohl et al., 2020 (Gohl et al., 2020). Briefly, the integrity of the extracted RNA was

119 analyzed as described previously. After RNA quality and integrity was checked, RT-qPCR was

120 also performed as described previously. RNA was also processed through the amplicon-based

121 sequencing method that utilizes adapter tails with the ARTIC network v3 primers, allowing for a

122 more efficient library preparation (Itokawa et al., 2020). Sequencing was also performed as

123 previously described using a MiSeq 600 $\square$ cycle v3 kit following manufacturer's instructions.

124 After sequencing, the paired ends were joined using PANDAseq (Masella et al., 2012) .

125 Unaligned reads were aligned to Wuhan-Hu-1 SARS-CoV-2 genome (MN908947.3) using BWA

126 (Li and Durbin, 2010; Wu et al., 2020). The Ivar software package was used for trimming and

127 filtering reads (Grubaugh et al., 2019). Ivar was also used to call variants and generate consensus

128 sequences. The consensus sequences were then strain typed using Pangolin (github.com/cov-

129 lineages/pangolin). Genome coverage plots were created using custom R scripts. Phylogenetic

130 tree was created using the Nextstrain web interface (Hadfield et al., 2018)(v0.14.2, commit:

131 f62d906, build 655).

133 RESULTS AND DISCUSSION

134 The present study evaluated a modified sequence capture approach, namely tailed

135 amplicon sequencing, for the detection of SARS-CoV-2 in the saliva of infected individuals [21].

136 Detection of SARS-CoV-2 in the saliva of infected individuals, both symptomatic and

137 asymptomatic, has expanded the toolbox of methods for the detection and diagnostics of the 
medRxiv preprint doi: https://doi.org/10.1101/2021.05.19.21257217; this version posted May 21, 2021. The copyright holder for this preprint (which was not certified by peer review) is the author/funder, who has granted medRxiv a license to display the preprint in perpetuity.

All rights reserved. No reuse allowed without permission.

138 virus. While RT-PCR and RT-qPCR are the standard methods for the detection of SARS-CoV-2

139 in various sample types, tailed amplicon sequencing approaches are also capable of identifying

140 SARS-CoV-2 in the saliva of infected individuals. Notably, results from the present study

141 showed that the tailed amplicon sequencing approach was successful in the identification of

142 various SARS-CoV-2 variants in human saliva (Table 1). Results also showed the suitability of

143 OMNIgene ${ }^{-O O R A L ~ O M E-505 ~ f o r ~ s u f f i c i e n t ~ S A R S-C o V-2 ~ R N A ~ r e c o v e r y ~ f o r ~ t a i l e d ~ a m p l i c o n ~}$

144 sequencing. Moreover, storage of saliva samples at room temperature using OMNIgene ${ }^{\bullet} \cdot \mathrm{ORAL}$

145 OME-505 for up to 15 days further supports the capacity of this collection device to capture

146 saliva composition at the time of collection, essential for SARS-CoV-2 diagnostics and

147 surveillance. While upper and lower respiratory tract specimens were first to be recommended

148 for SARS-CoV-2 diagnosis, saliva has gained acceptance as a suitable, non-invasive sample

149 type. Indeed, saliva has been included in numerous FDA Emergency Use Authorizations for the

150 purpose of SARS-CoV-2 diagnosis, including CRL Rapid Response ${ }^{\mathrm{TM}}$. The OMNIgene ${ }^{\circledR} \cdot \mathrm{ORAL}$

151 OME-505 saliva collection device, which has received EUA for SARS-CoV-2 sample collection,

152 allows for self-collection and to circumvent the need to store samples on ice or frozen.

153

154 Table 1. Summary of relevant metadata associated with saliva samples including: Pangolin

155 lineage which indicates the strain identity, Nexclade clade identification which shows the

156 phylogenetic lineage of the variant, qPCR Ct value for diagnosis, number of raw fastq reads, read

157 depth on the genome after trimming primers, percent coverage of the genome after trimming and

158 the number of variants (mutations) identified using iVar. 
medRxiv preprint doi: https://doi.org/10.1101/2021.05.19.21257217; this version posted May 21, 2021. The copyright holder for this preprint (which was not certified by peer review) is the author/funder, who has granted medRxiv a license to display the preprint in perpetuity.

All rights reserved. No reuse allowed without permission.

\begin{tabular}{|l|l|l|l|l|l|l|l|l|l|}
\hline $\begin{array}{l}\text { sample } \\
\text { ID }\end{array}$ & Lineage & Clade & Location & Ct value & $\begin{array}{l}\text { from } \\
\text { sample } \\
\text { collection } \\
\text { to RNA } \\
\text { extraction }\end{array}$ & $\begin{array}{l}\text { Raw } \\
\text { Read } \\
\text { Pairs }\end{array}$ & $\begin{array}{l}\text { after } \\
\text { trimming }\end{array}$ & $\begin{array}{l}\text { (\%) After } \\
\text { Trimming }\end{array}$ & $\begin{array}{l}\text { variants } \\
\text { identified }\end{array}$ \\
\hline A & B.1.2 & 20G & Belton, MO & 27.01 & 15 & 192151 & 2316.21 & 99.96 & 18 \\
\hline B & B.1 & $20 \mathrm{C}$ & $\begin{array}{l}\text { Wilmington, } \\
\text { DE }\end{array}$ & 14.01 & 12 & 260188 & 2413.47 & 99.44 & 21 \\
\hline C & B.1.2 & 20G & Bronx, NY & 16.50 & 3 & 233789 & 2547.39 & 99.73 & 29 \\
\hline D & B.1.1.22 & 20B & $\begin{array}{l}\text { Blacklick, } \\
\text { OH }\end{array}$ & 17.40 & 7 & 137894 & 1571.84 & 99.96 & 29 \\
\hline E & P.2 & 20B & Orient, OH & 17.64 & 11 & 166102 & 2166.38 & 99.76 & 27 \\
\hline F & B.1.427 & 20C & $\begin{array}{l}\text { Manhattan, } \\
\text { KS }\end{array}$ & 17.90 & 4 & 135078 & 1527.50 & 99.91 & 30 \\
\hline G & B.1.2 & 20G & Carson, CA & 18.28 & 2 & 212666 & 2146.30 & 99.81 & 22 \\
\hline H & B.1.1.7 & 20I/501Y.V1 & Topeka, KS & 18.55 & 7 & 202621 & 2527.93 & 99.83 & 39 \\
\hline
\end{tabular}

163 provided near complete genomes (>99.4\% average genome coverage) for all eight samples

164 tested (Table 1 and Figure 1). In addition, the tailed amplicon method produced a relatively

165 uneven genome coverage balance. Indeed, this has been noted previously when comparing the

166 tailed amplicon method with the ARTIC network protocol (Gohl et al., 2020). One feasible

167 explanation for this unevenness in genome coverage is the better balance of the untailed primers

168 utilized in the ARTIC network protocol. Nevertheless, near complete SARS-CoV-2 genomes

169 were obtained in the present study, which may improve insights into virus mutations, evolution,

170 and adaptation (e.g., increased transmissibility and infectivity) compared to evolutionary

171 relationships across spike protein sequences alone. Unlike specific genes, complete or near

172 complete genomic sequences provide the most high-resolution information that allows

173 determination of variant and strain relatedness during outbreaks and pandemics. Thus, the

174 development of cost-effective and less time-consuming protocols to determine genomic

175 sequences is of importance. In addition, near complete genome information may also aid in the

176 classification of SARS-CoV-2 variants into strains. SARS-CoV-2 strain level resolution using

177 tailed amplicon sequencing approaches could potentially aid to bridge mutations within SARS- 
medRxiv preprint doi: https://doi.org/10.1101/2021.05.19.21257217; this version posted May 21, 2021. The copyright holder for this preprint (which was not certified by peer review) is the author/funder, who has granted medRxiv a license to display the preprint in perpetuity.

All rights reserved. No reuse allowed without permission.

178 CoV-2 genomes at a global scale, which in turn may aid to understand virus transmission and

179 population dynamics. Variant level resolution of SARS-CoV-2 may also facilitate the

180 identification of novel target regions for vaccine development and therapeutics, particularly

181 regions across SARS-CoV-2 genomes that may be shared across variants and potential strains.

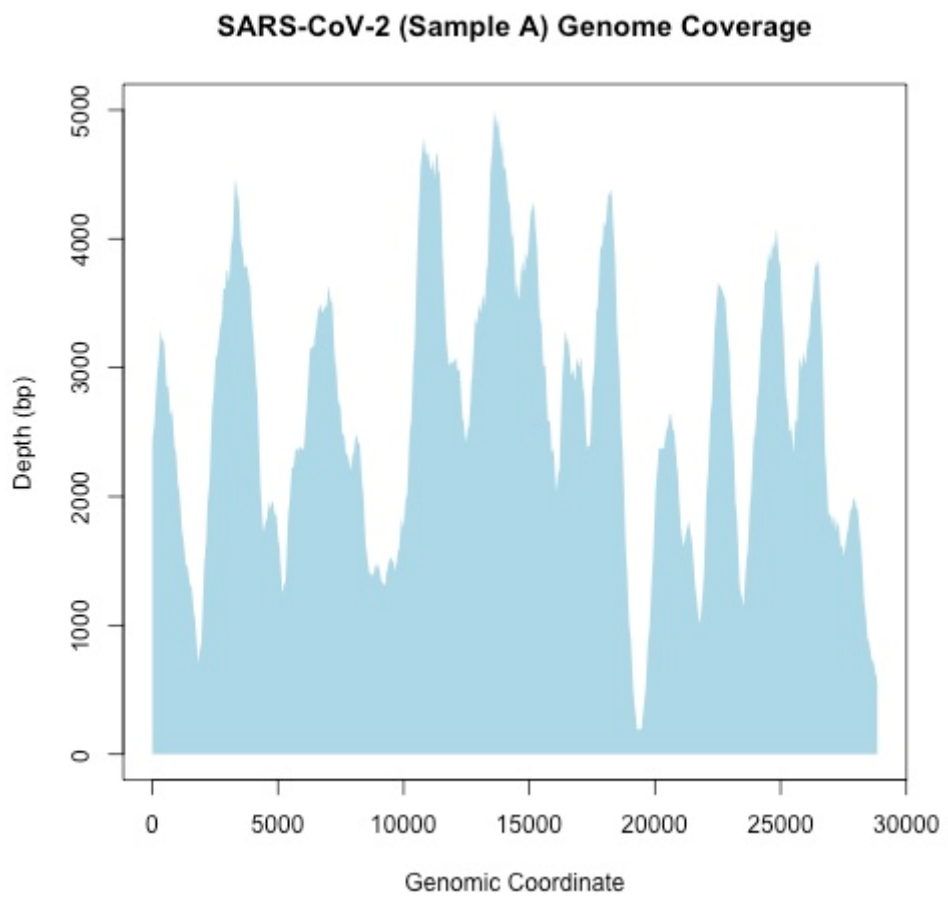

183 Figure 1. Representative example of SARS-CoV-2 genome coverage. Graph illustrates that the

184 combination of sample collection and sequencing methodology is sensitive enough to capture

185 most of the genome with very high coverage.

Near complete genomic sequences obtained using the tailed amplicon sequencing enabled

188 deciphering phylogenetic relationships across the various SARS-CoV-2 variants identified in the

189 saliva of the infected individuals in comparison with known clades (Figure 2). Results show

190 that, overall, the tailed amplicon method described above is sensitive enough to resolve, not only

191 large-scale genomic differences across different clades, but also differences within clades. 
medRxiv preprint doi: https://doi.org/10.1101/2021.05.19.21257217; this version posted May 21, 2021. The copyright holder for this preprint (which was not certified by peer review) is the author/funder, who has granted medRxiv a license to display the preprint in perpetuity.

All rights reserved. No reuse allowed without permission.

192 Phylogenetic relatedness may further contribute to the understanding of the pathogenic dynamics

193 of SARS-CoV-2 and associated strains over time and link these genetic variations to specific

194 geographical regions, which in turn can target genomic surveillance efforts.

195

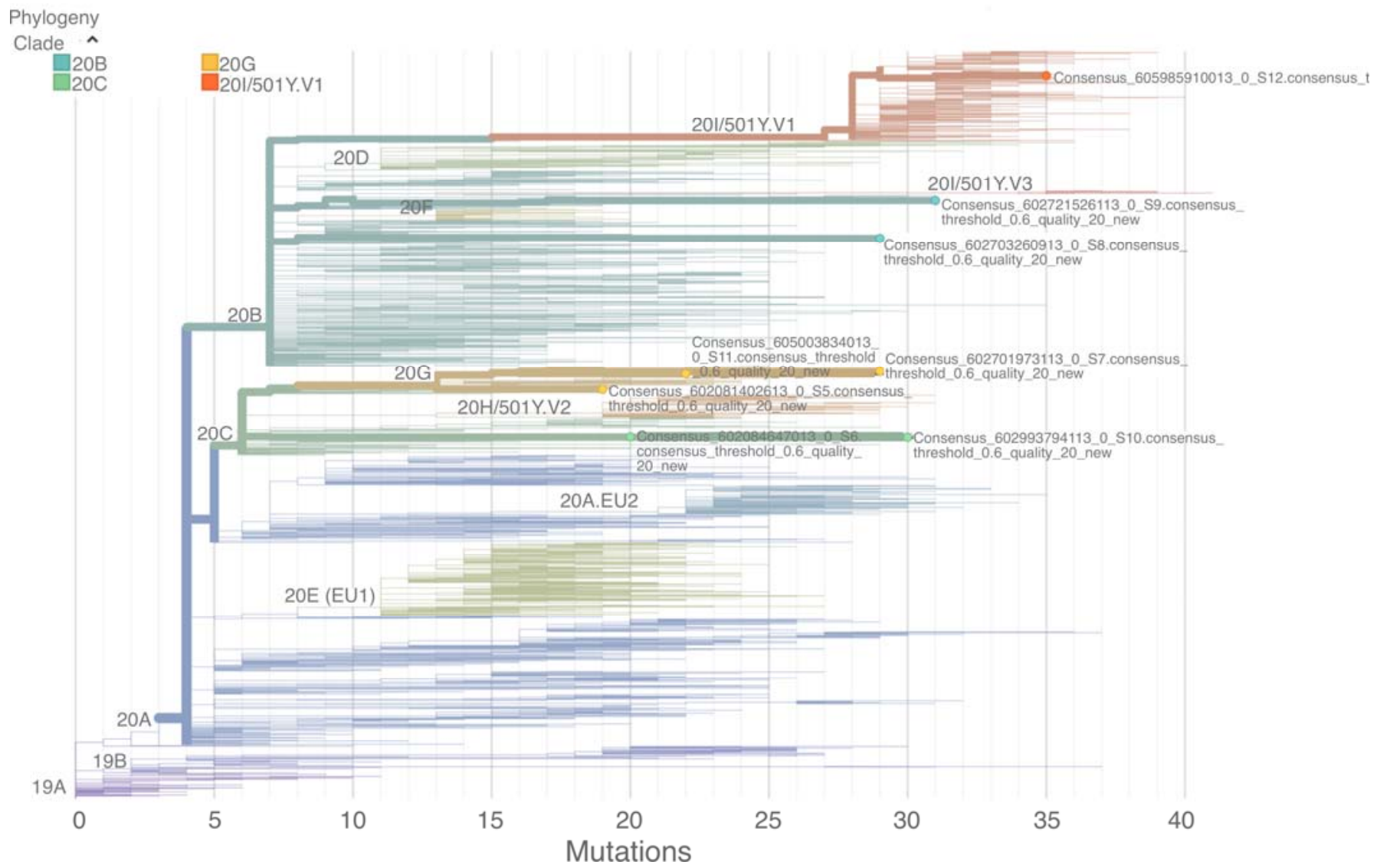

197 Figure 2. Phylogenetic analysis of the SARS-CoV-2 variants using Nextstrain clades. Figure

198 shows that the methodologies described above are sensitive enough to resolve, not only large-

199 scale genomic differences across different clades, but also differences within clades. 
medRxiv preprint doi: https://doi.org/10.1101/2021.05.19.21257217; this version posted May 21, 2021. The copyright holder for this preprint (which was not certified by peer review) is the author/funder, who has granted medRxiv a license to display the preprint in perpetuity.

All rights reserved. No reuse allowed without permission.

The present study evaluated tailed amplicon sequencing as a suitable approach for the

205 detection of SARS-CoV-2 variants in the saliva of infected individuals collected using

206 OMNIgene $® \bullet O R A L ~ O M E-505$. Near complete genome sequences were obtained using the

207 evaluated method, which in turn facilitated phylogenetic analysis with various SARS-CoV-2

208 variants. Near complete or complete genome sequences from SARS-CoV-2 variants continue to

209 be invaluable in disease control and prevention efforts during the COVID-19 pandemic; thus, the

210 evaluation of time- and cost-effective methods such as tailed amplicon sequencing is essential.

212 Author contributions

213 AG-data analysis, figure generation and manuscript draft editing. TSR-writing and editing of

214 original manuscript draft. HLF-sample collection and screening for positive samples RI-

215 conceptualization, and manuscript draft editing.

\section{Acknowledgements}

218 We thank Mike Tayeb, Geoffrey M. Graham and Austin Udocor for reviewing the manuscript

219 draft.

\section{$221 \quad$ Funding}

222 No funding was received for this study.

\section{Informed Consent and Release Statement}

225 Written informed consent and release statement has been obtained from the patient(s) to publish

226 this paper. 
medRxiv preprint doi: https://doi.org/10.1101/2021.05.19.21257217; this version posted May 21, 2021. The copyright holder for this preprint (which was not certified by peer review) is the author/funder, who has granted medRxiv a license to display the preprint in perpetuity.

\section{Institutional Review Board Statement}

229 The study is exempt under 45 CFR $\S 46.104(d)(4)$, because the research involves the use of

230 identifiable private information/biospecimens; and information, which may include information

231 about biospecimens, is recorded by the investigator in such a manner that the identity of the

232 human subjects cannot readily by ascertained directly or through identifiers linked to the

233 subjects, the investigator does not contact the subjects, and the investigator will not re-identify

234 subjects.

235

236 Conflict of interest

237 AG and TSR are current employees of Diversigen Inc. RI is a current employee of DNA

238 Genotek.

240 Data availability

241 SARS-CoV-2 sequence genomes are available on the Global Initiative on Sharing Avian

242 Influenza Data (GISAID) site under IDs EPI_ISL_2156824, EPI_ISL_2156826,

243 EPI_ISL_2156827, EPI_ISL_2156821, EPI_ISL_2156810, EPI_ISL_2156811,

244 EPI_ISL_2156823, EPI_ISL_2156808.

246 References

247 Bonaldo MC, Ribeiro IP, Lima NS, dos Santos AAC, Menezes LSR, da Cruz SOD, et al.

248 Isolation of Infective Zika Virus from Urine and Saliva of Patients in Brazil. PLoS Negl Trop

249 Dis 2016. https://doi.org/10.1371/journal.pntd.0004816. 
medRxiv preprint doi: https://doi.org/10.1101/2021.05.19.21257217; this version posted May 21, 2021. The copyright holder for this preprint (which was not certified by peer review) is the author/funder, who has granted medRxiv a license to display the preprint in perpetuity.

All rights reserved. No reuse allowed without permission.

De Carvalho Cardoso ES, De Santos Jesus BL, da Silva Gomes LG, Sousa SMB, Gadelha SR,

251 Marin LJ. The use of saliva as a practical and feasible alternative to urine in large-scale

252 screening for congenital cytomegalovirus infection increases inclusion and detection rates. Rev

253 Soc Bras Med Trop 2015. https://doi.org/10.1590/0037-8682-0200-2014.

254 Chu AWH, Chan WM, Ip JD, Yip CCY, Chan JFW, Yuen KY, et al. Evaluation of simple

255 nucleic acid extraction methods for the detection of SARS-CoV-2 in nasopharyngeal and saliva

256 specimens during global shortage of extraction kits. J Clin Virol 2020.

257 https://doi.org/10.1016/j.jcv.2020.104519.

258 Gohl DM, Garbe J, Grady P, Daniel J, Watson RHB, Auch B, et al. A rapid, cost-effective tailed

259 amplicon method for sequencing SARS-CoV-2. BMC Genomics 2020.

260 https://doi.org/10.1186/s12864-020-07283-6.

261 Grubaugh ND, Gangavarapu K, Quick J, Matteson NL, De Jesus JG, Main BJ, et al. An

262 amplicon-based sequencing framework for accurately measuring intrahost virus diversity using

263 PrimalSeq and iVar. Genome Biol 2019. https://doi.org/10.1186/s13059-018-1618-7.

264 Hadfield J, Megill C, Bell SM, Huddleston J, Potter B, Callender C, et al. NextStrain: Real-time

265 tracking of pathogen evolution. Bioinformatics 2018.

266 https://doi.org/10.1093/bioinformatics/bty407.

267 Han P, Ivanovski S. Saliva-friend and foe in the COVID-19 outbreak. Diagnostics 2020.

268 https://doi.org/10.3390/diagnostics10050290.

269 Itokawa K, Sekizuka T, Hashino M, Tanaka R, Kuroda M. A proposal of alternative primers for

270 the ARTIC Network's multiplex PCR to improve coverage of SARS-CoV-2 genome sequencing.

271 BioRxiv 2020.

272 Khadse S V., Bajaj G, Vibhakar P, Nainani P, Ahuja R, Deep G. Evaluation of specificity and 
medRxiv preprint doi: https://doi.org/10.1101/2021.05.19.21257217; this version posted May 21, 2021. The copyright holder for this preprint (which was not certified by peer review) is the author/funder, who has granted medRxiv a license to display the preprint in perpetuity.

All rights reserved. No reuse allowed without permission.

273 sensitivity of oral fluid for diagnosis of hepatitis B. J Clin Diagnostic Res 2016.

274 https://doi.org/10.7860/JCDR/2016/17319.7107.

275 Kilian M, Chapple ILC, Hannig M, Marsh PD, Meuric V, Pedersen AML, et al. The oral

276 microbiome - An update for oral healthcare professionals. Br Dent J 2016.

277 https://doi.org/10.1038/sj.bdj.2016.865.

278 Kwok H, Chan KW, Chan KH, Chiang AKS. Distribution, persistence and interchange of 279 epstein-barr virus strains among PBMC, plasma and saliva of primary infection subjects. PLoS

280 One 2015. https://doi.org/10.1371/journal.pone.0120710.

281 Leon LAA, De Almeida AJ, De Paula VS, Tourinho RS, Villela DAM, Gaspar AMC, et al.

282 Longitudinal Study of Hepatitis A Infection by Saliva Sampling: The Kinetics of HAV Markers

283 in Saliva Revealed the Application of Saliva Tests for Hepatitis A Study. PLoS One 2015.

284 https://doi.org/10.1371/journal.pone.0145454.

285 Li D, Zhang J, Li J. Primer design for quantitative real-time PCR for the emerging Coronavirus

286 SARS-CoV-2. Theranostics 2020. https://doi.org/10.7150/thno.47649.

287 Li H, Durbin R. Fast and accurate long-read alignment with Burrows-Wheeler transform.

288 Bioinformatics 2010. https://doi.org/10.1093/bioinformatics/btp698.

289 Li Y, Ren B, Peng X, Hu T, Li J, Gong T, et al. Saliva is a non-negligible factor in the spread of

290 COVID-19. Mol Oral Microbiol 2020. https://doi.org/10.1111/omi.12289.

291 Masella AP, Bartram AK, Truszkowski JM, Brown DG, Neufeld JD. PANDAseq: Paired-end

292 assembler for illumina sequences. BMC Bioinformatics 2012. https://doi.org/10.1186/1471-

293 2105-13-31.

294 Noah K, Fred T, Vlad S, Agatha B, Laura D, Siri K, et al. Self-collected oral fluid and nasal

295 swabs demonstrate comparable sensitivity to clinician collected nasopharyngeal swabs for 
medRxiv preprint doi: https://doi.org/10.1101/2021.05.19.21257217; this version posted May 21, 2021. The copyright holder for this preprint (which was not certified by peer review) is the author/funder, who has granted medRxiv a license to display the preprint in perpetuity.

Covid-19 detection. MedRxiv 2020. https://doi.org/10.1101/2020.04.11.20062372.

297 Parizad Elaheh Gholami, Parizad Eskandar Gholami, Khosravi A, Amraei M, Valizadeh A,

298 Davoudian A. Comparing HBV viral load in serum, Cerumen, and saliva and correlation with

299 HBeAg serum status in patients with chronic hepatitis B infection. Hepat Mon 2016.

300 https://doi.org/10.5812/hepatmon.30385.

301 Pérez Cataluña A, Chiner-Oms Á, Cuevas Ferrando E, Díaz-Reolid A, Falcó I, Randazzo W, et

302 al. Detection Of Genomic Variants Of SARS-CoV-2 Circulating In Wastewater By High-

303 Throughput Sequencing 2021.

304 Takeuchi Y, Furuchi M, Kamimoto A, Honda K, Matsumura H, Kobayashi R. Saliva-based pcr

305 tests for sars-cov-2 detection. J Oral Sci 2020. https://doi.org/10.2334/josnusd.20-0267.

306 To KKW, Tsang OTY, Leung WS, Tam AR, Wu TC, Lung DC, et al. Temporal profiles of viral

307 load in posterior oropharyngeal saliva samples and serum antibody responses during infection by

308 SARS-CoV-2: an observational cohort study. Lancet Infect Dis 2020.

309 https://doi.org/10.1016/S1473-3099(20)30196-1.

310 Valentine-Graves M, Hall E, Guest JL, Adam E, Valencia R, Shinn K, et al. At-home self-

311 collection of saliva, oropharyngeal swabs and dried blood spots for sars-cov-2 diagnosis and

312 serology: Postcollection acceptability of specimen collection process and patient confidence in

313 specimens. PLoS One 2020. https://doi.org/10.1371/journal.pone.0236775.

314 Wang WK, Chen SY, Liu IJ, Chen YC, Chen HL, Yang CF, et al. Detection of SARS-associated

315 coronavirus in throat wash and saliva in early diagnosis. Emerg Infect Dis 2004.

316 https://doi.org/10.3201/eid1007.031113.

317 Wu F, Zhao S, Yu B, Chen YM, Wang W, Song ZG, et al. A new coronavirus associated with

318 human respiratory disease in China. Nature 2020. https://doi.org/10.1038/s41586-020-2008-3. 
medRxiv preprint doi: https://doi.org/10.1101/2021.05.19.21257217; this version posted May 21, 2021. The copyright holder for this preprint (which was not certified by peer review) is the author/funder, who has granted medRxiv a license to display the preprint in perpetuity. All rights reserved. No reuse allowed without permission.

319 Yoon JG, Yoon J, Song JY, Yoon SY, Lim CS, Seong H, et al. Clinical significance of a high

320 SARS-CoV-2 viral load in the Saliva. J Korean Med Sci 2020.

321 https://doi.org/10.3346/JKMS.2020.35.E195.

322 Zhang T, Wu Q, Zhang Z. Probable Pangolin Origin of SARS-CoV-2 Associated with the

323 COVID-19 Outbreak. Curr Biol 2020. https://doi.org/10.1016/j.cub.2020.03.022.

324 Zhou P, Yang X Lou, Wang XG, Hu B, Zhang L, Zhang W, et al. A pneumonia outbreak

325 associated with a new coronavirus of probable bat origin. Nature 2020.

326 https://doi.org/10.1038/s41586-020-2012-7. 